\title{
Køn og teknologiforståelse i folkeskolen
}

\author{
Pia Susanne Frederiksen, lektor, UCNord, psf@ucn.dk
}

\begin{abstract}
Resume
Der er i disse år et stort fokus på, hvordan man kan styrke elevernes teknologiforståelse i folkeskolen, og der initieres mange projekter, bl.a. det nationale forsøgsprojekt med teknologiforståelse i skolen. En bekymring er, at disse projekter ofte ikke inddrager eller tager hensyn til de kønnede problemstillinger, der kan knytte sig til feltet. Det kan bl.a. handle om elevers og læreres kønnede forventninger og fordomme, når det gælder køn og teknologi.

Denne artikel bygger på fund fra en kvalitativ caseanalyse, der er lavet i en 2. klasse. Klassen deltager i det nationale forsøgsprojekt med teknologiforståelse. Fundene viser på den ene side, hvordan traditionelle køns-koder og kønsstereotyper reproduceres i undervisningen. På den anden side viser de også, hvordan en eksperimenterende rammesætning af undervisningen, hvor eleverne har stor indflydelse på indhold og arbejdsformer, synes at åbne mulighed for nye praksisser, identiteter og svækkede kønsstereotyper.
\end{abstract}

Nøgleord: køn, teknologi, kønsstereotyper, folkeskole

\begin{abstract}
This presentation is based on findings from a qualitative case analysis conducted in a second grade, which participated in the Danish national project 'technology understanding'. The findings show how traditional gender stereotypes are reproduced in the classroom, however, they also show how an experimental framework with a high degree of student involvement in defining content and working methods, seems to open up opportunities for new practices, identities and weakened gender stereotypes.
\end{abstract}

Keywords: gender, technology, gender stereotypes, primary school 


\section{Problemet med den manglende opmærksomhed på køn og teknologi}

Der er fra mange sider et stort fokus på, hvordan man kan styrke elevernes teknologiforståelse i folkeskolen i disse år. Det sker ud fra en erkendelse af, at vi lever i et digitaliseret samfund i stadig hastigere udvikling, og at eleverne skal klædes på i forhold til kunne anvende digitale teknologier, men også i forhold til at kunne forholde sig kritisk og reflekteret til teknologiens funktioner (fx konferencen 'Fremtiden er digital', Styrelsen for It og Læring, februar 2018).

Der udvikles og afprøves forskellige tiltag, der kan styrke elevernes teknologiske kompetencer. Blandt andet har alle nye 4. klasser fra skoleåret 2018 fået en micro:bit, som skal være et redskab til at lære dem at kode og tænke kreativt med teknologi, og mange skoler udstyrer deres elever med personlige computere, som skal styrke anvendelsen af it i undervisningen. Sidst og ikke mindst er der i øjeblikket søsat et storstilet projekt af Undervisningsministeriet, hvor der arbejdes på at udvikle og etablere tiltag, der bredt har til formål at styrke elevernes teknologiforståelse i folkeskolen. Projektet skal resultere i, at der udvikles Fælles Mål for teknologiforståelse som nyt fag og som ny faglighed i skolen (emu.dk).

En bekymring i forhold til dette konkrete projekt såvel som i forhold til andre projekter, der sætter elevernes teknologikompetencer og -forståelse på dagsordenen i folkeskolen, kan være, at der i projekternes tilrettelæggelse og gennemførelse ikke synes at være et særligt bevidst fokus og opmærksomhed på kønsproblematikker og udfordringer i forhold hertil, når det gælder teknologiforståelse og børns tilgang til og tilegnelse heraf.

Det er velkendt, at drenge og piger ikke indtager den teknologiske 'scene' på samme måde. Alene et blik på teknologitunge uddannelser og brancher på arbejdsmarkedet taler deres eget sprog. Således har optaget af kvindelige studerende på it-uddannelser siden 2008 og indtil 2016 konstant ligget på 27 procent. De seneste par år er der sket en lille positiv stigning til 29 procent (Ufm, 2020). Endnu færre kvinder arbejder i it-branchen. Endvidere viser undersøgelser, at piger ofte mangler selvtillid og tro på egne evner, når det gælder teknologiske fag og discipliner (Lauritsen, 2018; Bundsgaard et al., 2018; Sørensen et al., 2000).

Bl.a. peger den store internationale ICILS 2018-undersøgelse, der blandt andre omfatter danske elever i 8. klasse, på, at der er meget store forskelle mellem danske pigers og drenges opfattelse af deres egne kompetencer i 
relation til it. Det samme gælder i forhold til deres forestillinger om et fremtidigt arbejdsliv med it. Selv om pigerne i undersøgelsen faktisk klarer sig gennemsnitligt bedre i testen af computer- og informationskompetencer end drengene, ligger deres tro på egne evner, når det gælder tekniske aktiviteter, i bund. Det er således bemærkelsesværdigt, at forskellen på danske drenges og pigers tiltro til egne teknologiske evner er markant større, end det gælder for forskellen mellem drenge og piger på dette punkt i de øvrige deltagende lande (Bundsgaard et al., 2018).

En årsag til pigernes manglende tiltro til egne teknologiske evner kan være, at piger og drenge tidligt i deres liv mødes kønsstereotypt, og at børnene selv udvikler kønsstereotype opfattelser af, hvad der er henholdsvis pige- og drengeaktiviteter (Lauritsen, 2018). Det er fx velkendt, at det især er drenge, der i stort omfang er optaget af computerspil.

En nyere svensk undersøgelse (Sultan et al., 2019) afdækkede i tråd hermed, at piger i 9-12-årsalderen er præget af kønsstereotype opfattelser af sig selv og ofte adopterer en social identitet som værende ikke- teknisk. Det samme billede tegner sig i en række andre europæiske studier (Vekiri et al., 2009; Virtanen \& Ikonen, 2015; Sinatra et al., 2018).

Erfaringerne fra et andet projekt herhjemme, netværket FabLab@school ${ }^{1}$ peger desuden på, at det ikke er ligegyldigt, hvordan piger inviteres ind i det teknologiske univers, hvis de skal engageres og interesseres. Ifølge antropolog Rachel Smith er det nødvendigt, at der skabes en ny digital kultur i skolen, der i højere grad er på pigernes præmisser. Det involverer bl.a., at der i øget grad fokuseres på samarbejde, det eksperimenterende og det kreative (Smith, 2018).

Endelig har tidligere undersøgelser vist, at lærernes kønnede forestillinger og forventninger til eleverne ser ud til at påvirke elevernes deltagelse i teknologiske aktiviteter (Jensen et al. 2010).

Erfaringerne er altså, at piger og drenge står med forskelligt udgangspunkt, når det handler om teknologi. Det peger på, at der er et stort behov for at sætte fokus på de strukturelle, kønsmæssige problemstillinger og udfordringer, der stadig knytter sig til feltet; her ikke mindst stærke, traditionelle kønsstereotyper. Hvis ikke der sker et brud med sådanne struk-

1 FabLab@school er et netværk, der arbejder forskningsbaseret med digital fabrikation, designtænkning og empowerment af fremtidens elever og lærere. På hjemmesiden beskriver netværket sig som en samarbejdsplatform for udvikling og deling af undervisningsforløb. https:// fablabatschool.dk/ 
turer, er faren, at pigernes manglende selvtillid på det teknologiske område fortsat vil præge deres uddannelsesvalg og ikke mindst fravalg af teknologiske uddannelser. I et bredere perspektiv vil det begrænse deres mulighed for at deltage i et fremtidigt samfund, hvor forståelse af de tekniske aspekter af digitaliseringen kan være en forudsætning for at tage stilling til tidens centrale problemstillinger (Bundsgaard et al., 2018).

Det synes at være særligt vigtigt at have øje på sådanne problemstillinger, når der søsættes store teknologiprojekter i folkeskolen, der har til formål at forberede eleverne til aktivt at deltage i et øget digitaliseret samfund. Hvis kønsstereotyper overses eller bagatelliseres, kan faren være, at skolen og lærerne ikke formår at bryde dem eller endda ubevidst kan være med til at forstærke dem.

\section{Formålet med undersøgelsen}

Vi ved altså fra forskning på feltet, at kønsstereotyperne eksisterer og præger pigers og drenges selvtillid og opfattelse af teknologi. Der synes dog at mangle dybere viden om, hvor og hvornår kønsstereotyperne opstår, og hvordan de mere præcist sætter sig igennem i forhold til kønnenes forskellige tilgange til teknologi. Særligt mangler der viden om, hvilken betydning pigers og drenges kønskonstruktioner har for tilgangen til teknologi. Og der mangler viden om, hvilken rolle skolen og skolens fxllesskaber spiller i den sammenhæng, herunder viden om pigers og drenges møde med den digitale kultur i skolen.

Formålet med denne undersøgelse har været at undersøge sådanne spørgsmål. Mere præcist har interessen været at undersøge: Hvordan påvirker læreres og elevers kønskonstruktioner deres tilgang til teknologiforståelsesundervisningen? Og hoordan reproducerer eller udfordrer den didaktiske rammesætning kønsstereotyper?

Undersøgelsen er foretaget $\mathrm{i}$ en klasse, der har deltaget $\mathrm{i}$ forsøget med teknologiforståelse i folkeskolen.

\section{Undersøgelsens teoretiske ramme}

Projektet henter analytisk inspiration hos den britiske uddannelsessociolog Basil Bernstein og hans begreber om 'kulturel reproduktion', 'klassifikation' og 'pædagogisk rammesætning' (Bernstein, 2001; 2003). 
Meget kort gengivet har Bernstein et skarpt og kritisk blik på den kulturelle reproduktion af normer og ikke mindst af magtforhold, der ofte sker i uddannelsessammenhæng og i pædagogiske kontekster. Til at forstå, hvordan den kulturelle reproduktion sker i en pædagogisk sammenhæng, anvender han begreberne om klassifikation og pædagogisk rammesætning. Klassifikation handler om, at fx individer klassificeres i kategorier. Det kan blandt andet være i kønskategorierne dreng og pige. Klassifikationen eller opdelingen kan være stærkere eller svagere. En stærk klassifikation kan være, hvor der er en stærkt kønsopdelt og kønsstereotyp tænkning og kultur i en pædagogisk kontekst. Ifølge Bernstein har klassifikation af individer to funktioner. På den ene side regulerer den relationerne mellem individer. På den anden side regulerer den også individernes interne relationer, det vil sige individets identitet. Bernstein hævder, at klassifikation af individer altid, hvad enten den er stærk eller svag, er bærer af magtrelationer.

Det andet begreb, der har betydning i forhold til at forstå mekanismerne i kulturel reproduktion, er som nævnt pædagogisk rammesætning. Den pædagogiske rammesætning handler dels om forventninger i forhold til individets (elevens) karakter og adfærd, dvs. reglerne for den sociale orden, og for det andet om underviserens tilrettelæggelse af undervisningen i forhold til valg af indhold, rækkefølge, tempo og kriterier for erhvervelse af viden, dvs. reglerne for den diskursive orden. Lige som klassifikation af elever kan være henholdsvis stærk eller svag, gælder det samme for den pædagogiske rammesætning. I en stærk rammesætning vil læreren udøve stærk kontrol over, hvad der skal foregå i undervisningen, og hvordan det skal foregå. Og omvendt i en svag rammesætning.

Ifølge Bernstein vil der i en pædagogisk sammenhæng, der er præget af stærk klassifikation og en stærk pædagogisk indramning, ofte ske en ubevidst og ukritisk gengivelse af forestillinger, identiteter og praksisser. Der vil med andre ord ske en kulturel reproduktion. Det kan fx være en overlevering af traditionelle kønsnormer og kønskoder. Hvis eleverne omvendt mødes af et miljø med svag klassifikation og med svag rammesætning, hvor de har lov til at være kreative og selv bidrage, kan det potentielt svække klassifikationen og ændre ideer, identiteter og praksisser.

Selv om Bernstein udviklede sine begreber for mere end tredive år siden, synes de stadig at have betydelig forklaringskraft, når ønsket er at forstå mekanismerne bag kulturel reproduktion. Og en anden af styrkerne ved hans begreber er, at de kan bruges heuristisk som analytiske pejlemærker til at undersøge, hvad der foregår i en konkret pædagogisk kontekst. 


\section{Undersøgelsesdesign og datagrundlag}

Fundene, der skal præsenteres i det følgende, bygger på et dybdegående, kvalitativt casestudie, der er foretaget i en 2. klasse i en dansk folkeskole.

Et casestudie har til formål at skabe en teoretisk generalisering, og det vil være muligt at diskutere, om identificerede mønstre under bestemte betingelser med sandsynlighed vil optræde i situationer under lignende betingelser (Yin, 2010).

Casestudiet er en del af en større undersøgelse i et komparativt design, hvor der både indgår en 2. klasse og en 8. klasse. Men det er altså alene fund fra 2. klasse, der præsenteres her.

Undersøgelsen er foretaget på en relativ stor byskole i Jylland. I caseklassen er der 10 piger og 15 drenge. Klassen er valgt ud fra flere kriterier: For det første har det været ønsket, at skolen og klassen skulle deltage i det nationale forsøg med teknologiforståelse som fag. For det andet har et kriterium selvsagt været, at skolen, læreren, eleverne og deres forældre har ønsket at indgå $i$ undersøgelsen. For det tredje er klassen valgt ud fra et kriterium om social diversitet, når det gælder forældres beskæftigelses- og uddannelsesniveau.

Læreren karakteriserer klassen som en god og samarbejdende klasse, hvor der ikke er mange elever, der har adfærds- og disciplinære problemer.

Caseanalysens datagrundlag er observations- og interviewdata. Observationerne er optegnet som feltnoter (Hastrup, 2010), mens interviewene er semistrukturerede (Brinkmann \& Tanggaard, 2010). Der er gennemført i alt 16 timers observationer i klassen samt interviews med 20 elever, både drenge og piger. Desuden er der gennemført to interviews med den lærer, der underviste klassen i faget teknologiforståelse på undersøgelsestidspunktet. Dataene blev indsamlet i efteråret 2019 og i starten af 2020.

\section{Undersøgelsestemaer}

Undersøgelsens forskningsspørgsmål, Hvordan påvirker læreres og elevers kønskonstruktioner deres forståelse af og tilgang til 'teknologi', og hvordan reproducerer eller udfordrer den didaktiske rammesætning kønsstereotyper?, er brudt ned i en række temaer, der har været styrende for dataindsamlingen: a) Hvordan opfatter/oplever piger og drenge undervisningen i teknologiforståelse? b) Hvilken rolle spiller klassens kultur, dvs. de lokale forhandlinger af populær maskulinitet og femininitet, for opfattelsen af 'teknologi'? c) Hvad er henholdsvis pigers og drenges erfaringer med 'teknologi'? d) Hvornår synes 
piger, at teknologi og teknologiundervisningen er interessant? e) Hvilke forventninger har lærerne til drenge og piger, når det gælder teknologi? f) Hvad karakteriserer den didaktiske rammesætning af undervisningen i teknologiforståelse? I undersøgelsen af den didaktiske rammesætning har der været et særligt fokus på indhold og arbejdsformer i forbindelse med teknologiforståelsesundervisningen.

I observationerne har der været særligt fokus på elevernes deltagelses- og samarbejdsmønstre og på undervisningens rammesætning.

\section{Etik}

Eleverne, der deltager i undersøgelsen, er sikret ekstern anonymitet (Brinkman \& Tanggaard, 2010). Deres rigtige navne er ændret, og det vil ikke være muligt for udefrakommende at identificere enkeltelever. Når det gælder intern anonymitet, kan det ikke afvises, at eleverne selv og læreren i enkelte tilfælde vil kunne identificere informanter. Det vurderes dog, at fundene er fremstillet $i$ en sådan form, at det ikke vil kunne skade disse elever. Læreren, der deltager i undersøgelsen, er tilsvarende anonymiseret og formodes ikke at kunne identificeres af udefrakommende.

\section{Fund fra caseanalysen}

I det følgende skal der redegøres for nogle af hovedfundene i caseanalysen. Fundene diskuteres og sammenlignes med andre fund fra forskning $\mathrm{i}$ køn og teknologi/naturfag og i lyset af Bernsteins begreber om pædagogiske koder.

\section{Ingen væsentlig forskel på drenge- og pigeaktiviteter}

Der er ikke i analysen noget der tyder på, at eleverne i caseklassen generelt insisterer på en stærk kønsopdeling eller trækker på stærke, stereotype versioner af maskulinitet og femininitet.

Piger og drenge leger oftest med en eller flere af samme køn, men en del af eleverne leger frivilligt sammen på tværs af køn både i skolen og fritiden. På lærernes foranledning er eleverne desuden inddelt $i$ legegrupper fire dage i ugen, hvor de skal lege sammen i varierende tværkønnede grupper. Dette arbejde med klassekulturen synes at modvirke en stærk kønsopdeling i klassen. 
Mange udtrykker, at der ikke er forskel på, hvad drenge og piger leger. Således fortæller Oskar, der både leger med drenge og piger:

\section{Det er lidt forskelligt, hoad vi laver. Nogle gange leger vi mor, far og børn, og nogle gange leger vi spejder og sådan lidt'. Jeg synes ikke, der er forskel på at lege med piger og drenge. Nogle af pigerne gider ikke lege krig. (Oscar)}

Oscar opdeler ikke i væsentlig grad aktiviteterne i drenge- og pigeaktiviteter. Han konstaterer, at pigerne ikke gider lege krig, men der synes ikke her, eller generelt hos eleverne, at være tale om en stærk klassifikation af henholdsvis pige- og drengeaktiviteter. De fleste piger udtrykker på samme måde, at der ikke er væsentlig forskel på, hvad drenge og piger laver. Der er dog eksempler på, at nogle af især drengene laver en sådan klassifikation. Som her hvor Benjamin refererer til henholdsvis pige- og drengeaktiviteter:

\section{Piger, de leger med dukker, som jeg ikke gør. Vi (drengene, red.) spiller $i$ hvert fald fodbold mere end pigerne. Anna og Elsa, det er ikke noget for mig, det er i hvert fald ikke noget for mig. Det er mest for piger. Jeg tror kun, der er nul af drengene, der leger med det. (Benjamin)}

Benjamin opdeler dukker og fodbold som henholdsvis pige- og drengeaktiviteter. Han nævner desuden Disney-figurerne Anna og Elsa, som de har haft et tema med i teknologiforståelse. Med sin stærke stemmemæssige betoning af, at det i hvert fald ikke er noget for ham - eller de andre drenge, udtrykker han en afstand til temaet som et 'pigetema'. Pigeaktiviteter klassificeres dermed som mindreværdige.

Der er dog også et eksempel på, at en anden dreng downgrader drengeaktiviteter i forhold til pige-aktiviteter: "Spil, det er nærmest det eneste, (drengene, red.) de gider. Og fodbold og sådan. Frederikke, hun er sådan en, der gider lege alt muligt. Piger de leger bare ... alt muligt med fantasi og sådan" (Storm).

Man får her det indtryk, at Storm mener, pigernes aktiviteter er mere varierede og fantasifulde end drengenes. Han bryder således delvist med det kulturelt standardiserede billede af legeaktiviteter, når det gælder køn, som Benjamin trækker på. 


\section{Både piger og drenge er begejstrede for teknologiundervisning}

Umiddelbart synes elevernes kønskonstruktioner i caseklassen da heller ikke at have afgørende betydning for deres opfattelse af deres nye fag teknologiforståelse; i hvert fald ikke når det gælder interessen for faget og deres selvtillid i forhold til det. Både piger og drenge i klassen er begejstrede for faget og opfatter det som et af deres bedste fag, hvis ikke deres yndlingsfag. Som en af pigerne udtrykker det:

\section{Det er mit yndlingsfag. Man bruger en masse teknologi, og man prøver nye spil. Det er sjovt. Vi har også brugt Book Creator. Vi har leget med det, valgt baggrunde og andre sjove ting. Ja, os piger, vi snakker om, at det er fedt med teknologi, og at vi er interesserede i det. Det er sådan et fedt fag, så jeg gider ikke kun have det om tirsdagen. (Frederikke)}

Frederikke giver her udtryk for, at pigerne indbyrdes taler om, at teknologiforståelse er et fag, de interesserer sig for, og hun ville ønske, de havde mere undervisning i det.

Når eleverne bliver bedt om at vurdere, om de er gode til faget, så svarer alle pigerne tillige, uden undtagelser, at de selv er gode til faget. Og det samme gælder drengene.

Hverken pigerne eller drengene mangler altså selvtillid i faget, og der er ikke noget, der umiddelbart tyder på, at pigerne adopterer en social identitet som ikke-tekniske (jf. Sultan et al., 2019).

Klassens lærer har da også noteret sig, at eleverne er begejstrede for teknologiundervisningen:

\section{Jeg synes, det er virkelig dejligt. Vi har nogle børn, som virkelig elsker den her teknologi, især mange piger, faktisk. Det er jeg overrasket over. Efter vi havde det her teknologi sidste år, fik en af pigerne det her tek- nologisæt i fødselsdagsgave. Jeg tænker, det er ikke helt billigt. (Hans)}

Hans udtrykker her både glæde over, at eleverne er glade for teknologiundervisningen, og overraskelse over, at især pigerne er så glade for faget. 


\section{Drengene har mere erfaring med computerteknologi}

Selv om både piger og drenge er begejstrede for teknologiforståelse, synes der dog at være stor forskel på deres erfaring med computere og computerspil. Næsten alle drengene spiller computerspil i fritiden, mens det kun gælder to ud af de 10 piger i klassen.

Drengenes erfaring med computerspil betyder, ifølge læreren, at drengene har en anden grundlæggende fortrolighed med computeren i undervisningen, hvor de er foran mange af pigerne i forhold til $\mathrm{fx}$ at logge ind og at navigere rundt på computeren. Og det kommer til udtryk $i$, at mange af drengene har et sprog til at tale om begreber og figurer i computerspillene, hvor pigerne ofte ikke kender de elementære funktioner i spillene. Når det gælder programmering og robotteknologi, er drenge og piger, ifølge læreren, dog på samme forudsætningsniveau.

\section{Der er forskel på pigers og drenges interesseorientering i teknologiundervisningen}

Der er ikke umiddelbart noget, der tyder på, at pigerne foretrækker at arbejde med 'pigede' temaer i undervisningen. De synes lige så begejstrede for Star Wars-temaet som for Elsa og Anna-temaet.

Der er dog en bemærkelsesværdig forskel på, hvad henholdsvis piger og drenge fremhæver som det, de godt kan lide ved teknologiforståelsesundervisningen. Næsten alle drenge fremhæver, at det, de godt kan lide, er at få lov til at sidde med/arbejde med computeren; og at få lov til at spille spil og lave ting, som de i forvejen er gode til: "Ja, det er nok, fordi man kommer til at lave mange programmeringer. Jeg kan godt lide spil og sådan noget. Jeg er rigtig god til spil. Og bygge Lego" (Karl). Karl udtrykker her, at han kan få lov til at dyrke det, han i forvejen er meget optaget af og god til, nemlig spil. Men altså også at lege med Lego, som de bruger til at bygge robotter med i undervisningen.

Et par af pigerne fremhæver også det at bruge teknologi og prøve nye spil som spændende (jf. Frederikke ovenfor); men generelt er det aspekter ved undervisningens rammesætning, pigerne betoner som det interesseskabende ved undervisningen. Og her fremhæves ofte variationen i undervisningen: "Jeg kan godt lide teknologiforståelse. At vi laver en hel masse ting. Og alt sammen noget forskellig noget" (Emma). 
Ud over variationen fremhæver pigerne ofte det legende og eksperimenterende som vigtigt for interessen i faget (jf. Frederikke-citatet ovenfor). Dette synes således at være i overensstemmelse med erfaringerne med, hvad der kan engagere pigerne, i FabLab@school (se side 3). Et par af pigerne nævner desuden lærerens pædagogiske og personlige kvaliteter som det, der primært motiverer dem i undervisningen: (Jeg kan lide teknologiundervisning, fordi, red.) "Hans er sød, og forklarer tingene, så vi ved, hvad det er" (Amalie). Ud over at nævne betydningen af, at hun godt kan lide læreren, betoner Amalie her hans evne til at forklare, så hun kan forstå det. Hun giver således indirekte udtryk for, at læreren formår at give hende en mestringsoplevelse i undervisningen.

Mønstrene i elevernes begrundelser for at kunne lide teknologiundervisningen kan pege i retning af, at drengenes interesse har noget, der ligner en mere 'individuel' karakter, mens pigernes interesse synes at have en mere 'situationel' karakter.

Begreberne individuel og situationel interesse refererer til to forskellige former for interesse eller motivation, som interesseforskere særligt inden for naturfagsområdet ofte skelner imellem (Krapp, 2002; Troelsen, 2006; Albrechtsen, 2009; Dohn, 2014). Situationel interesse er en betegnelse for situationsafhængig interesse, dvs. interesse stimuleret $i$ en bestemt situation. Det er specifikke aspekter ved det omgivende miljø, der fremkalder en opmærksomhed og affektiv reaktion hos eleven. Nogle interesseforskere betragter situationel interesse som en umiddelbar positiv følelsesreaktion på noget nyt og spændende, og den vil i udgangspunktet være kortvarig (Albrechtsen, 2009). Individuel interesse refererer derimod til en persons vedholdende lyst til at engagere sig i det, der har interessen. Der er tale om en fastholdt interesse, hvor eleven udvikler en tendens til at opsøge interesseobjektet på egen hånd.

For at en interesse fx i teknologi skal være vedvarende og måske resultere i tilvalg af området/faget fx i en uddannelsessammenhæng, vil det ifølge interesseforskerne være afgørende, at interessen er blevet individuel.

Med ovennævnte in mente kan man fristes til at karakterisere de fleste pigers interesse i teknologiforståelse i caseklassen som mere 'skrøbelig' end de fleste drenges. Lærerens evne til at rammesætte undervisningen forekommer således at kunne spille en større rolle for at fastholde pigernes interesse, end den gør for drengenes vedkommende. 


\section{For pigerne skal robotter skal have en funktion}

Selv om pigerne ikke nødvendigvis skal arbejde med stereotype pigetemaer for at fange interesse for teknologiundervisningen, bliver det synligt især i forbindelse med undervisningen i robotteknologi, at piger og drenge har forskellig tilgang til opgaverne. Mens drengene ser ud til at være optaget af robotten og konstruktionen af den i sig selv, synes det for pigerne at være vigtigt, at robotten skal have en funktion, og robotten må gerne være en altruistisk figur, der har en god mission. Pigerne iscenesætter således ofte deres robotter mere omfattende end drengene og giver opmærksomhed til hele iscenesættelsen. Robotten er kun en del af den. Iscenesættelsen kan eksempelvis handle om, at robotten er en læge, der skal redde verden.

Denne måde at arbejde med/lege med robotteknologien giver mulighed for at konstruere personlig mening, et princip, der vides at have positiv effekt på motivation i naturfagssammenhæng (Dohn, 2014). Det handler bl.a. om at kunne forbinde forforståelse og tidligere erfaringer med ny information. For pigerne giver iscenesættelsen mulighed for at koble den nye teknologiske viden til kendte og meningsfulde temaer i deres øvrige lege- og erfaringsunivers. Drenge synes i højere grad end pigerne direkte at kunne koble fx robotkonstruktion til tidligere meningsfulde konstruktionserfaringer, blandt andet med Lego.

Det forekommer således vigtigt, at undervisningen i teknologiforståelse tilrettelægges, så både piger og drenge har mulighed for at koble til deres tidligere/kendte erfaringsunivers.

\section{Kønnede forventninger til eleverne}

Som nævnt ovenfor giver læreren eksplicit udtryk for, at han er overrasket over, at der er mange piger, der har taget teknologien til sig. Denne overraskelse, kan man sige, er i sig selv et udtryk for, at han ikke på forhånd havde forventninger om, at piger ville interessere sig så meget for teknologien og for faget som drengene.

Også mere indirekte synes hans opfattelse af eleverne at være præget af forskellige forventninger til henholdsvis piger og drenge. Det kommer bl.a. til udtryk, da han bedes beskrive alle eleverne og deres tilgang til teknologifaget og til undervisningen. Selv om mange af pigerne selv udtrykker, at teknologiforståelse er deres yndlingsfag, og at de opfatter sig selv som dygtige til det, så beskriver læreren deres tilgang til faget i følelsesmæssigt 
'flade' og, fristes man til at sige, stereotype vendinger. Alle pigerne karakteriseres om ikke ens, så på en ensartet måder: "Jamen, hun er nysgerrig og har ja-hatten på..., og ehm... hun er... hun er også spørgende til tingene..., eh.. jeg synes... absolut" (Hans).

Pigen, han her karakteriserer, er Frederikke, som selv beskriver sit engagement $\mathrm{i}$ faget $\mathrm{i}$ begejstrede vendinger. Det er gennemgående, at læreren $\mathrm{i}$ karakteristikken af pigerne fremhæver deres indstilling til arbejdet, at de er søde, samarbejdsvillige, de har 'ja-hatten' på.

I modsætning hertil beskrives drengene i mere varierede og, især de fagligt dygtige drenge, $i$ langt mere udfoldede og passionerede vendinger:

\section{Jamen Storm, for filen da, han har bare, han har knækket koden $i$ alt det her. Han er... han excellerer, han eh, han er nok, han er nok den bedste, jeg sådan har. Jeg tror bare, han har en dyb interesse i det. Der er bare et eller andet, der fanger. Han holder fokus, han vil gerne hjælpe de andre, hois han er færdig. (Hans)}

I citatet her fremhæver Hans både Storms faglige dygtighed og hans positive indstilling til at hjælpe andre. Det er dog gennemgående, at især i karakteristikken af de fagligt dygtige drenge er det deres faglige kompetencer, der betones.

Set i lyset af Bernsteins begreber om klassifikation synes der her at være tale om, at læreren laver en subtil, ubevist og relativ stærk klassifikation af eleverne på baggrund af køn. Mens pigerne overvejende bliver set for deres samarbejdskompetencer, synes han at se de fagligt dygtige drenge overvejende for deres faglige kompetencer. Man kan formode, at denne klassifikation over tid, via lærerens måde at møde eleverne på, kan præge elevernes identiteter og selvforståelse i forhold til teknologiforståelsesfaget.

\section{Pigerne skal holde styr på drengene}

Det er imidlertid ikke alle drengene, der karakteriseres positivt af læreren. Der er en gruppe af drenge, der kan have koncentrationsvanskeligheder, især når de er sammen.

Og noget tyder på, at sammensætningen af eleverne i kønnede makkerpar har sin begrundelse i den problemstilling og ikke alene i ønsket om, at drenge og piger skal arbejde sammen på tværs. Således svarer Hans på spørgsmålet om, hvorfor eleverne er parret dreng/ pige: 


\section{Hvorfor de er parret pigeldreng..eh..ja, det har vi jo egentlig gjort mange af stederne. Ehm, det har været, eh, (pause, red.) det ved jeg faktisk ikke, altså. Hvis jeg havde parret dem i andre fag, hois det ikke havde været teknologiforståelse, så havde jeg også parret dem pige og dreng. $J a$, det tror jeg, jeg havde... det er den der gamle antagelse, som jeg også selv var en del af, da jeg gik i skole, at... pigerne, de kan være med til..., at der kan udlignes lidt på..på det..på de vilde drenge og de søde piger og, ..eller hoad det nu ellers er. (Hans)}

Læreren bruger så at sige pigerne som hjælpere, der skal holde styr på de ukoncentrerede drenge. Og det sker ifølge ham selv ikke kun i teknologiforståelsesfaget. Han karakteriserer det som en gammel antagelse, der sætter sig igennem, og man fornemmer, at han i interviewsituationen selv kommer til at forholde sig lidt kritisk, reflekterende til den. Man kan da også hævde, at det er et eksempel på en ureflekteret kønsstereotyp opfattelse af piger og drenge, og altså ikke bare hos denne lærer, der sætter sig igennem som en struktur og danner praksisser og i sidste ende måske også identiteter (Bernstein, 2001). Eleverne er i hvert fald godt klar over, hvorfor de er i dreng/pige-makkerpar: "Lærerne synes, det giver drengene noget andet, så man ikke fjoller så meget" (Anders). Anders her, og de øvrige elever, får indirekte lært, at det er pigernes ansvar at holde fast $\mathrm{i}$ opgaven og holde drengene på sporet.

Selv om der er en generel accept af at arbejde dreng/pige hos eleverne, er der da også nogle af pigerne, der forholder sig kritisk til den 'kønnede' arbejdsdeling, der kan opstå i makkerparrene. Se nedenfor.

\section{Både svag og stærk rammesætning af undervisningen i teknologiforståelse}

I tråd med de retningslinjer, der ligger for forsøget med teknologiforståelse (emu.dk), er undervisningen i caseklassen tilrettelagt i en åben og eksperimenterende ramme med stor variation og med en høj grad af deltagelse og indflydelse fra elevernes side. Det gælder i forhold til at præge indholdet $\mathrm{i}$ det, der arbejdes med, men det gælder også i forhold til, hvordan man skal arbejde med det. Læreren sætter nogle få klare rammer og regler for arbejdet i faget, som han til gengæld konsekvent kræver bliver overholdt, men ellers er der en høj grad af råderum for eleverne til at eksperimentere og arbejde på det niveau, de nu er på. Og som nævnt ser elevernes begejstring for teknologiforståelse, og her ikke mindst pigernes, da også i høj grad ud til 
at hænge sammen med denne rammesætning af undervisningen. Som her Christine, der begejstret fortæller: "Fordi der går man ind på det, der hedder LegoWedo, og så kan man selv vælge en figur, og når man er færdig med at bygge den, kan man få den til at køre og alt muligt" (Christine).

Christine fremhæver her det motiverende i at få lov til at vælge figuren selv og at få lov til at eksperimentere med den. Og netop friheden til at præge indholdet fremhæves af flere af eleverne som motiverende: "Det er sjovest, når Hans ikke fortæller os, hvad vi skal gøre, for så arbejder vi bare løs. Så er der ikke et specielt emne. Man bestemmer selv, hvad man skal gøre og skrive" (Frederikke). Ud over at nævne det motiverende i selv at kunne præge indholdet betoner Frederikke her også glæden ved at kunne arbejde i sit eget tempo eller bare at kunne "arbejde løs".

Lige som eleverne sætter pris på at kunne præge indhold og arbejdsmåde, tillægger de det også stor værdi selv at kunne bestemme, hvor de fysisk kan placere sig med arbejdsopgaverne. Tillige med faglokalet har de mulighed for at placere sig ved borde, i sofaer eller på gulvet et selvvalgt sted i et meget stort fællesområde. Som Sara her udtrykker det: "Hans er en god lærer, han lader os arbejde, hvor vi vil" (Sara).

Endelig fremhæver eleverne det motiverende $\mathrm{i}$ at få lov til at samarbejde med andre elever i forbindelse med undervisningen. De sætter pris på at arbejde i makkerpar. Som nævnt er der en generel accept af at blive sat sammen dreng/pige, selv om de fleste af eleverne ville vælge deres bedste kammerat at være makker med, hvis de selv kunne vælge. Der er dog nogle af pigerne, der forholder sig kritisk til den arbejds- og rollefordeling, der kan opstå hos makkerparrene. Som Anna her: "Drengene er dovne. Det er os (piger, red.), der skal gøre alt arbejdet. Hente computeren og skrive" (Anna).

Observationerne viser, at det til gengæld overvejende er drengene, der sidder med computerne, hos de par, hvor der er en elev af hvert køn, især i starten af timen, hvor der skal logges ind mv. Selv om reglen er, at man skal skiftes.

Den tydelige sammenhæng mellem den didaktiske rammesætning af undervisningen og elevernes motivation for faget, her ikke mindst pigernes, som analysen har vist, synes at harmonere med tidligere forskningsfund om forhold, der kan fremme elevernes motivation i naturfagsundervisning (Paris et al., 1998; Dohn, 2014).

Disse fund tyder på, at hvis målet er at stimulere elevers interesse og motivation, og ikke mindst pigers, så skal undervisningen tilrettelægges ud fra bestemte didaktiske designprincipper, de seks c'er: 
Constructing personal meaning (forbinde forforståelse og tidligere erfaringer med ny information), choice (give eleverne reelle valg), challenge (udfordre den enkelte elev optimalt), control (give elever en vis grad af selvbestemmelse), collaboration (samarbejde, gruppearbejde) og consequences that promote selv-efficacy (undgå præstationskultur, tilskynde til deling af information).

Alle c'erne synes at være til stede i caseklassens teknologiundervisning.

Dohn (2014) peger i øvrigt på, at netop disse designprincipper, der kan fremme motivation og selvregulering, også har potentiale til at udvikle en situationel interesse til en mere individuel interesse.

\section{Overlevering af kønsstereotyper, men også åbning for nye identiteter}

Med reference til Bernsteins begreber om henholdsvis stærk og svag pædagogisk rammesætning må man umiddelbart karakterisere rammesætningen af teknologiundervisningen i caseklassen som forholdsvis svag; i hvert når fald når det gælder den diskursive orden, der handler om valg af indhold, rækkefølge, tempo og kriterier for erhvervelse af viden. Eleverne har relativ stor indflydelse på, hvad der skal foregå i undervisningen, og hvordan. Når det gælder den sociale orden, dvs. forventninger i forhold til elevernes karakter og adfærd, er rammesætningen derimod præget af relativ stærk kontrol fra lærerens side. Som nævnt sætter han nogle få klare rammer og regler for arbejdet i faget, som han insisterer på bliver overholdt. Observationerne viser, at de indebærer: 1) at man skal være fuldstændig stille og lytte til lærerens instruktion, 2) man skal samarbejde i makkerpar, en dreng og en pige, 3) man skal skiftes til at sidde med computeren, når man arbejder i makkerpar, og 4) at man skal holde fokus i arbejdet.

De to sider af den pædagogiske rammesætning forekommer ikke i den konkrete pædagogiske praksis at være i modsætning til hinanden. Dele af den stærke sociale orden ser således ud til at være en forudsætning for, at den relativt svage rammesætning af den diskursive orden kan fungere. Set $\mathrm{i}$ lyset af Bernsteins teori om kulturel reproduktion kan man dog sige, at den stærke rammesætning af den del af den sociale orden, der handler om, at drenge og piger skal arbejde i makkerpar, med begrundelse i kønnede forventninger til eleverne, indebærer, at der sker en ubevidst og ukritisk overlevering af traditionelle kønsnormer. Denne overlevering af normer eller stereotype kønskoder forekommer at kunne blive forstærket af den relativt 
stærke klassifikation af eleverne, som kommer til udtryk i lærerens beskrivelser af eleverne.

Omvendt synes den løse pædagogiske rammesætning af teknologiundervisningen i øvrigt - dvs. pigers og drenges mulighed for at være kreative, at eksperimentere og arbejde på måder og med indhold, der opleves som meningsfulde - at kunne styrke ikke mindst pigernes motivation og interesse for teknologifaget og at kunne understøtte en positiv identitet hos dem som 'tekniske'. Heri kan således også ligge en åbning i forhold til at bryde med traditionelle normer, identiteter og praksisser på området.

\section{Sammenfattende konklusion og diskussion}

Det er velkendt, at piger og drenge står med et forskelligt udgangspunkt, når det handler om teknologi, og at der stadig knytter sig nogle strukturelle udfordringer til feltet, her ikke mindst stærke traditionelle kønsnormer og -stereotyper. Interessen i dette projekt har været at undersøge aspekter af, hvor og hvornår disse kønsstereotyper opstår. Der har været en særlig interesse $\mathrm{i}$ at frembringe viden om, hvilken betydning pigers og drenges kønskonstruktioner har for deres tilgang til teknologi, og om, hvilken rolle skolen og skolens fællesskaber spiller i den sammenhæng, herunder viden om pigers og drenges møde med den digitale kultur i skolen.

Fundene, der er beskrevet i denne artikel, er fra et kvalitativt casestudie foretaget i en 2. klasse, der har deltaget i forsøget med teknologiforståelse i folkeskolen.

Studiet har vist, at eleverne i caseklassen, både piger og drenge, er glade for teknologiundervisningen, og at pigerne på dette klassetrin ikke synes at have adopteret en social identitet som ikke-tekniske. Og hverken drenge eller piger trækker tilsyneladende på stærke versioner af maskulinitet og femininitet i klassens elevfællesskab. Det kan spille en rolle her, at der fra lærernes side bevidst arbejdes med klassekulturen, bl.a. med legegrupper, hvor drenge og piger leger på tværs.

Studiet har dog også vist, at der er forskel på drenges og pigers tilgang til teknologi, og at pigerne generelt synes at have en mere 'skrøbelig' identitet i forhold til teknologi end drenge. Den forekommer at være mere situationsbestemt end drengenes, der i højere grad har karakter af at være individuel og vedvarende. En del af forklaringen herpå kan være, at drenge allerede i 2. klasse har mere erfaring med teknologi end pigerne, især computertekno$\log$. 
Den pædagogiske rammesætning af teknologiundervisningen ser ud til at have stor betydning for især pigernes motivation og interesse i teknologiundervisningen. I caseklassen er undervisningen rammesat, så eleverne har mulighed for selv at vælge indhold, at være kreative, eksperimentere og arbejde på måder og med indhold, der opleves som meningsfyldt. Det ser ud til at understøtte en positiv identitet hos pigerne som 'tekniske'.

Samtidig viser studiet dog også, at eleverne på flere måder mødes med kønsstereotype forventninger i teknologiundervisningen, som potentielt fastholder piger og drenge i traditionelle roller. Det sker, når piger og drenge skal danne makkerpar, for at pigerne kan holde styr på drengene, og det sker mere subtilt, når læreren ubevidst laver en relativ stærk klassifikation af drenges og pigers kompetencer i forhold til teknologi.

Man kan formode at sådanne kønsstereotype forventninger og klassifikationer over tid utilsigtet kan præge elevernes selvforståelse i forhold til teknologiforståelsesfaget, og for pigernes vedkommende i negativ retning.

Samlet understøtter studiet således antagelsen om, at der er et behov for ikke at overse eller bagatellisere de kønsproblematikker, der kan knytte sig til teknologiske indsatser i folkeskolen, bl.a. det nationale forsøgsprogram med teknologiforståelse. Der er stadig stærke, traditionelle kønsnormer og kønsstereotyper på spil, som reproduceres. Med reference til Bernsteins begreber om pædagogiske koder kan man også sige, at der stadig forekommer klassifikationer af eleverne, der regulerer såvel relationerne mellem eleverne og elevernes interne relationer, altså deres identitet, på måder, som reproducerer kulturelle kønsnormer.

Men analysen har også vist, at kvaliteter i rammesætningen af undervisningen kan understøtte især pigernes interesse i faget. Igen med reference til Bernstein kan man sige, at den relativt svage rammesætning af den diskursive orden potentielt indeholder kimen til at kunne bryde med traditionelle kønsnormer, identiteter og praksisser på området. Det forekommer mindst lige så vigtigt at have øje for det.

Og fundene tyder på, at indskolingen kan være et vigtigt sted i skoleforløbet at sætte ind, hvis der skal ske et sådan brud. I indskolingen er der på mange skoler i forvejen ofte fokus på at arbejde med klassekulturen, dvs. adfærdsnormer, omgangsformer og samarbejdsrelationer i klassens fællesskab, og det er oplagt, at der her, som i caseklassen, kan arbejdes bevidst med at undgå stærke kønsopdelinger og dermed at imødegå stærke stereotyper i forhold til pige- og drengeaktiviteter. 
Og så tyder det altså på, at eleverne, og her vigtigst pigerne, i indskolingen endnu ikke er fastlåst i en kønnet identitet som henholdsvis teknisk eller ikke-teknisk. De har, lige som drengene, en åbenhed over for teknologien. Det forekommer at være vigtigt, at pigerne så at sige gribes her og mødes, så deres positive tekniske identitet og selvtillid bevares og styrkes.

Udfordringen kan være, at pigernes interesse i faget forekommer at være mere skrøbelig og situationel end drengenes, der ofte synes at være af mere 'indviduel' og vedholdende karakter. Man kan hævde, at det i sig selv er vigtigt, at den didaktiske rammesætning af teknologiundervisningen kan skabe selv en mere kortsigtet situationel interesse. At der vækkes en interesse. Men det gode spørgsmål er, om og hvordan man i givet fald kan udvikle også pigers interesse til at blive en mere stabil interesse i teknologi. Især hvis dagsordenen er at få flere piger til at tilvælge faget/området i en uddannelsessammenhæng, tyder det på, at det er afgørende, at interessen er blevet individuel.

Her kan det i første omgang være vigtigt at have fokus på betydningen af mestringsoplevelser. En del forskning peger på, at der er sammenhæng mellem det at klare sig godt og at kunne lide et fag. (fx Troelsen, 2005; Frederiksen, 2019). Mestringsoplevelser er formentlig ikke alene afgørende for, om en elev udvikler en vedvarende interesse for et fag, men sandsynligvis en forudsætning. Og man kan antage, at jo flere mestringsoplevelser, jo større er chancen for, at kimen til en vedvarende interesse skabes. Dette kalder på kvaliteter i den didaktiske rammesætning af undervisningen, der kan understøtte sådanne mestringsoplevelser, $\mathrm{fx}$ at undervisningen er tilrettelagt, så alle elever kan koble sig på, og at den enkelte elev ses og spejles i sin mestring af læreren. Her er det selvsagt af betydning, at læreren ikke ureflekteret har forskellige (kønnede) forventninger til henholdsvis pigers og drenges teknologikompetencer.

Og så forekommer det vigtigt, at den undervisning i teknologi, eleverne fortløbende møder og tilbydes videre i skoleforløbet i øvrigt, har nogle af de didaktiske kvaliteter, der ser ud til at kunne understøtte ikke mindst pigernes interesse og engagementet i emnet. Det kan således være vigtigt at fastholde og udvikle sådanne kvaliteter i en fremtidig rammesætning af undervisning i teknologiforståelse i folkeskolen.

Når dette er sagt, synes der at være behov for at frembringe yderligere viden på området. Det gælder bl.a. viden om den betydning, kønskonstruktioner i skolens fællesskaber kan have senere i skoleforløbet for pigers og drenges opfattelse af teknologi. Dette studie har således udelukkende haft 
fokus på elever tidligt i skoleforløbet. Og det gælder viden, der kan afdække, om både piger og drenge i en didaktisk rammesætning, som skitseret ovenfor, rent faktisk over tid potentielt udvikler en mere individuel interesse i teknologi.

Traditionelle kønsnormer, identiteter og praksisser stikker dybt, netop fordi de er kulturelt og strukturelt forankrede. Derfor ændres de ikke over kort tid og med hurtige snuptagsløsninger, heller ikke når det gælder teknologiområdet. Men en afgørende forudsætning for, at der sker ændringer, er, at der er en vedvarende opmærksomhed på kønnede problemstillinger - hos skolens lærere og hos professionelle aktører på området i øvrigt. Og at der forløbende udvikles og afprøves ny viden og ideer, der kan hjælpe ændringerne på vej.

\section{Referencer}

Albrechtsen, T.R.S. (2009). Interessebegrebet i ROSE-undersøgelsen. MONA: Matematik og Naturfagsdidaktik, (3), 7-20.

Bernstein, B. (2001). Pædagogiske koder og deres praksismodaliteter. I: Choullaraki, L., \& Bayer, M. (red.), Basil Bernstein. Pædagogik, diskurs og magt. Akademisk Forlag.

Bernstein, B. (2003). Class, Codes and Control: Towards a Theory of Educational Transmissions. Psychology Press.

Brinkmann, S., \& Tanggaard, L. (2010). Kvalitative metoder. Hans Reitzels Forlag.

Bundsgaard, J., Bindslev, S., Caeli, E.N., Pettersson, M., \& Rusmann, A. (2018). Danske elevers teknologiforståelse. Resultater fra ICILS undersøgelsen 2018. Aarhus Universitetsforlag.

Dohn, N.B. (2014). Motiverende og interesseskabende naturfagsundervisning. ntsnet.dk/Naturfagsdidaktik

emu.dk https://emu.dk/grundskole/teknologiforstaelse

Frederiksen, P. (2019). De 'vanskelige' drenge: Når dynamikker i skolens fællesskaber resulterer i stærke kønskonstruktioner og modstand mod skolens læringsdagsorden. Unge Pædagoger, 80(1), 29-35.

Hastrup, K. (2010). Feltarbejde. I: Brinkmann, S., \& Tanggaard L. (red.), Kvalitative metoder. Hans Reitzels Forlag.

Jensen, T., Krøjer, J., \& Hansen, K.G. (2010). Inklusion i interaktiv deltagelse $i$ folkeskolen: Et forskningsprojekt om køn, teknologi og læring. 'INDELTA'. Roskilde Universitet: Institut for Psykologi og Uddannelsesforskning (PAES).

Krapp, A. (2002). Structural and dynamic aspects of interest development: theoretical considerations from an ontogenetic perspective. Learning and Instruction, 12(4), 383-409.

Københavns Professionshøjskole et al. (2018). Forundersøgelse vedr. forsøg med teknologiforståelse i folkeskolens obligatoriske undervisning. https://xn--tekforsget-6cb.dk/wp-content/upl oads/2019/05Forunders\%C3\%B8gelse-vedr.-fors\%C3\%B8gmed-teknologiforst\%C3\%A5else-i-folkeskolens-obligatoriske- undervisning.pdf

Lauritsen, L. (2018). Hvordan skabes og brydes effekter af kønsstereotyper i STEM? Oplæg på konferencen Fremtiden er digital - Hvordan fär vi pigerne med til at skabe den? Styrelsen for It og Læring, februar 2018. 
Paris, S.G., Yambor, K.M., and Packard, B.W. (1998). Hands-on biology: A museum-schooluniversity partnership for enhancing students' interest and learning in science. The Elementary School Journal, 98(3), 267-288.

Smith, R. (2018). Oplæg på konferencen Fremtiden er digital - Hvordan fär vi pigerne med til at skabe den? Styrelsen for It og Læring, februar 2018.

Sultan, U.N, Axell, C., \& Hallström, J. (2019). What are they doing? Tool use and self-image of girls aged 9-12 when engaging in technology education. Linköping University.

Sørensen, H.B., \& Olesen, B. (red). (2000). Børn i en digital kultur. Forskningsperspektiver. Gads Forlag.

Troelsen, R. (2006). Unges interesse for naturfag - hvad ved vi, og hvad kan vi bruge det til? MONA: Matematik og Naturfagsdidaktik (2). https://tidsskrift.dk/mona/article/view/36447

Ufm (2020). https://ufm.dk/uddannelse/statistik-og-analyser/sogning-og-optag-pa-videregaende-uddannelser/2020/notat-8-kon-og-arets-optag.pdf

Undervisning og Forskningsministeriet First Lego Legue. https://ufm.dk/forskning-og-innovation/rumomradet/ brug-rummet/aktuelt/nyheder/first-r-lego-r-league-into-orbit

Vekiri, J., \& Chronaki, (2008). Gender issues in technology use: Perceived social support, computer self-efficacy and value beliefs, and computer use beyond school. Computers $\mathcal{E}$ Education, 51(3), 1392-1404.

Virtanen, S., Räikkönen, E., \& Ikonen, P. (2015). Gender-Based Motivational Differences in Technology, International Journal of Technology and Design Education, 25(2), 197-211.

Yin, R. (2019). Case Study Research: Design and Methods. SAGE Publications. 